\title{
PROGRAM PENGUNGKAPAN SUKARELA DALAM RANGKA MENINGKATKAN KEPATUHAN PAJAK DI MASA PANDEMI COVID-19
}

\author{
Ferry Irawan ${ }^{1 *}$, Punjung Raras ${ }^{2}$ \\ ${ }^{1)}$ ferry.irawa@pknstan.ac.id, Politeknik Keuangan Negara STAN \\ *penulis korespondensi
}

\begin{abstract}
Law Number 7 of 2021 concerning Harmonization of Tax Regulations (UU HPP) is a continuation of Law Number 11 of 2020 concerning Job Creation (UU Ciptaker) in terms of regulating provisions in the taxation sector. The HPP Law regulates several changes and the inclusion of new provisions including the Voluntary Disclosure Program (PPS). One of the main objectives of PPS is to increase taxpayer compliance. PPS is implemented based on the principles of simplicity, legal certainty and benefit. Community service activities are carried out through web seminars aimed at providing understanding to the public about PPS and its scope. The material presented in this webinar includes Indonesia's macroeconomic conditions, the impact of the pandemic situation, and the relationship between PSS and tax compliance. The webinar consists of three stages. First, presentation of material from resource persons 1. Second, presentation of material from resource persons 2. Third, question and answer session with participants. The number of webinar participants is around 300 who come from various professional backgrounds, such as students, academician, practitioners, and other professionals.
\end{abstract}

Keywords: Voluntary disclosure program, tax compliance, tax revenue

\begin{abstract}
Abstrak
Undang-Undang Nomor 7 Tahun 2021 tentang Harmonisasi Peraturan Perpajakan (UU HPP) merupakan kelanjutan dari Undang-Undang Nomor 11 Tahun 2020 tentang Cipta Kerja (UU Ciptaker) dalam hal pengaturan ketentuan di bidang perpajakan. UU HPP mengatur beberapa perubahan dan pencantuman ketentuan baru termasuk di antaranya Program Pengungkapan Sukarela (PPS). Salah satu tujuan PPS yang utama adalah meningkatkan kepatuhan wajib pajak. PPS dilaksanakan berdasarkan asas kesederhanaan, kepastian hukum dan dan kemanfaatan. Kegiatan pengabdian kepada masyarakat dilakukan melalui web seminar bertujuan untuk memberikan pemahaman kepada masyarakat mengenai PPS dan ruang lingkupnya. Materi yang disajikan dalam webinar ini antara lain kondisi makro ekonomi indonesia, dampak situasi pandemi, dan kaitan PSS dengan kepatuhan pajak. Pelaksanaan webinar terdiri dari tiga tahap. Pertama, penyajian materi dari narasumber 1. Kedua, penyajian materi dari narasumber 2. Ketiga, sesi tanya jawab dengan peserta. Jumlah peserta webinar sekitar 300 yang berasal dari berbagai latar belakang profesi, seperti mahasiswa, akademisi, praktisi, dan para profesional lainnya.
\end{abstract}

Kata Kunci : Program pengungkapan sukarela, kepatuhan pajak, penerimaan pajak

\section{PENDAHULUAN}

Di masa pandemi covid-19, pemerintah mengeluarkan berbagai kebijakan dengan tujuan untuk mendorong pemulihan ekonomi nasional. Di tahun 2021 Pemerintah menerbitkan Undang-Undang Nomor 7 Tahun 2021 tentang Harmonisasi Peraturan Perpajakan (UU HPP). UU HPP ini berlaku mulai Januari 2022 secara bertahap. Undang-undang ini diharapkan mampu mendongkrak penerimaan pajak melalui peningkatan kepatuhan wajib pajak. Salah satu program dalam UU HPP yang diharapkan dapat dimanfaatkan oleh masyarakat adalah program pengungkapan sukarela (PPS).

Apabila ditelaah lebih rinci terdapat persamaan dan perbedaan antara PPS dan pengampunan pajak (tax amnesty) tahun 2016. PPS disebut juga sebagai tax amnesty jilid II. Hal ini tidak keliru karena secara substansi, negara memberikan perlakuan yang serupa. Sebagai contoh, wajib pajak mengungkapkan harta bersih yang belum atau kurang diungkapkan dalam surat pernyataan sepanjang Direktur Jenderal Pajak belum menemukan data dan/atau informasi mengenai harta dimaksud. Terdapat dua skema dalam memanfaatkan PPS. Pertama, perolehan harta sejak tanggal 1 Januari 1985 sampai dengan tanggal 31 Desember 2015. Periode ini 


\section{PENGMASKU}

Volume 1 No. 2, Desember 2021

berlaku bagi wajib pajak baik orang pribadi maupun badan yang telah mengikuti program tax amnesty tahun 2016-2017. Skema kedua yaitu untuk perolehan harta mulai 1 Januari 2016 sampai dengan 2020 hanya berlaku bagi wajib pajak orang pribadi atas pengungkapan harta dimaksud wajib pajak wajib membayar besarnya pajak sebagaimana tercantum dalam UU HPP.

Di sisi lain, perbedaan yang signifikan adalah besaran tarif pajak yang lebih tinggi. Pengenaan tarif pajak pada PPS relatif lebih tinggi dibandingkan tarif pajak tax amnesty. Selain itu, pemerintah juga mengklaim bahwa otoritas pajak telah memiliki akses informasi yang lebih baik dibandingkan pada masa tax amnesty. Konsekuensinya adalah, otoritas pajak memiliki peluang untuk mengidentifikasi perolehan harta wajib pajak secara lebih luas. Untuk itu, wajib pajak diminta untuk lebih patuh dalam melaporkan harta sesuai dengan kondisi yang sesungguhnya.

Untuk memberikan pemahaman terhadap PPS terhadap seluruh kalangan masyarakat luas baik kaum akademisi maupun praktisi, perlu dilakukan upaya literasi. Literasi yang dilakukan oleh otoritas pajak mungkin masih belum dapat menjangkau seluruh lapisan masyarakat. Oleh karena itu, diperlukan upaya bersama untuk menyosialisasikan PPS. Secara spesifik, tujuan pengabdian kepada masyarakat ini adalah untuk memberikan pengetahuan kepada seluruh masyarakat dalam rangka mempersiapkan saat berlakunya PPS. Selain itu, program pengabdian masyarakat ini diharapkan menjadi sarana untuk memperkuat konsepsi wajib pajak terhadap pentingnya pajak sehingga kepatuhan pajak menjadi lebih baik. selanjutnya, penulis mengelaborasi metode pelaksanaan, hasil dan pembahasan, serta simpulan.

\section{METODE PELAKSANAAN}

Kegiatan pengabdian kepada masyarakat ini dilakukan dalam bentuk web seminar (webinar) melalui aplikasi zoom (Irawan, 2021). Di masa pandemi webinar menjadi alternatif yang tepat dan efisien. Fakultas Ekonomi dan Bisnis Universitas Pamulang (FEB UNPAM) merupakan penyelenggara kegiatan webinar. Secara teknis, pelaksanaan ini dikategorikan dalam tiga tahap. Pertama tahap persiapan. Selanjutnya adalah tahap pelaksanaan tahap terakhir adalah evaluasi. Hal-hal yang dilakukan pada tahap persiapan antara lain adalah mengidentifikasi kebutuhan webinar oleh pengabdi dan penyelenggara, termasuk juga pembahasan mengenai calon peserta, pendekatan dan teknis webinar, serta capaian yang diharapkan atas kegiatan webinar. Selain itu, untuk kebutuhan publikasi, dibuatkan flyer webinar (Gambar 1).

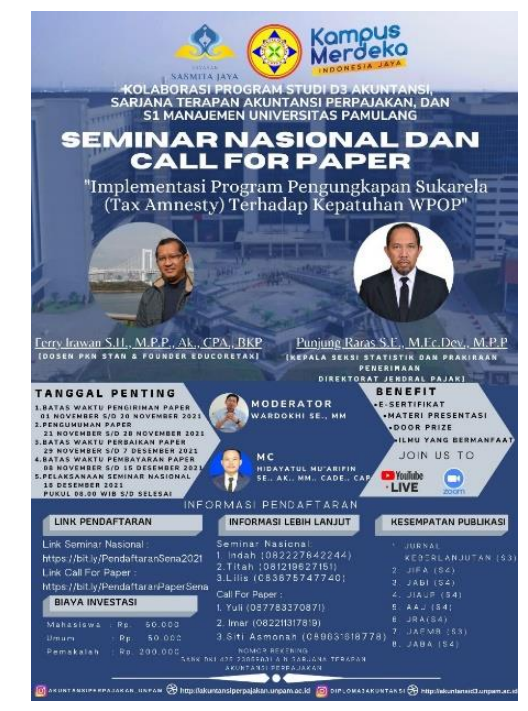

Gambar 1. Flyer Webinar

Tahap selanjutnya kedua yaitu pelaksanaan webinar. Webinar yang merupakan salah satu rangkaian kegiatan seminar dan call for paper diselenggarakan pada hari sabtu tanggal 18 


\section{PENGMASKU}

Volume 1 No. 2, Desember 2021

Desember 2021 mulai pukul 08.30 sampai dengan pukul 11.30 WIB. Jumlah peserta terdaftar sebanyak lebih kurang 300 orang terdiri dari mahasiswa dan dosen baik dari berbagai perguruan tinggi di Indonesia serta para praktisi bisnis dan pajak. Webinar dibuka oleh seorang master of ceremony (MC). Selanjutnya, diadakan dengan do'a bersama agar kegiatan webinar berjalan dengan lancar. Selanjutnya, terdapat sambutan dari Dekan FEB UNPAM dan diteruskan dengan penyampaian materi oleh dua orang narasumber, yaitu Punjung Raras, S.E., M.Ec.Dev, M.P.P. dan Ferry Irawan, M.P.P. Punjung Raras merupakan Kepala Seksi Statistik dan Prakiraan Penerimaan Direktorat Jenderal Pajak. Sedangkan Ferry Irawan merupakan dosen dan peneliti pada Politeknik Keuangan Negara STAN. Penyampaian materi oleh narasumber pertama terkait dengan kebijakan Direktorat Jenderal Pajak dalam PPS. Sedangkan penyampaian oleh narasumber kedua terkait dengan konsep dan model kepatuhan kepatuhan pajak yang dapat dicapai melalui PPS. Waktu yang dialokasi untuk kedua pemateri adalah 80 menit (Gambar 2).

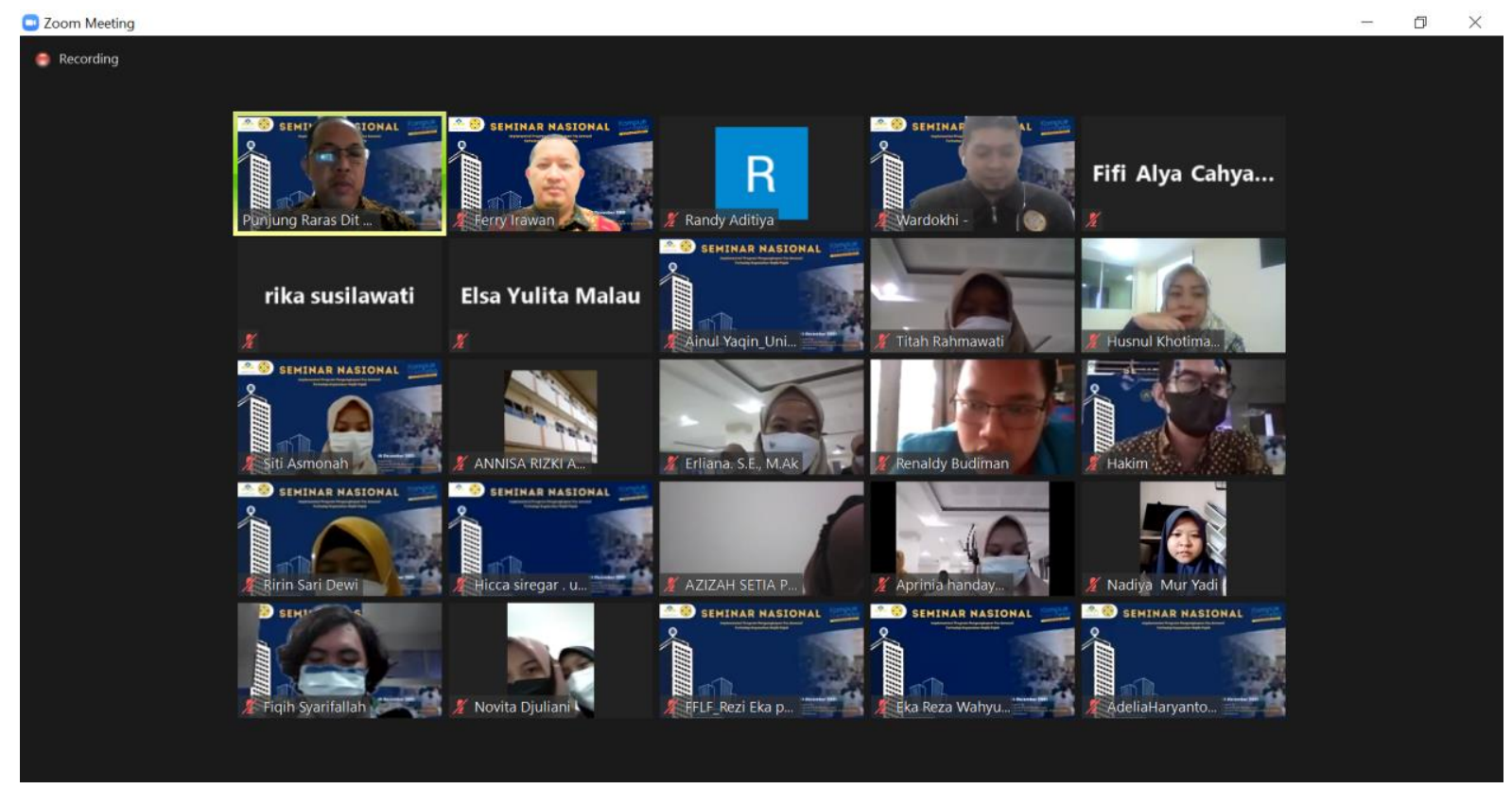

Gambar 2. Penyampaian Materi oleh Narasumber

Tahap berikutnya adalah evaluasi, yaitu meminta feedback dari para peserta melalui sesi tanya tanya yang dipandu oleh moderator. Moderator memberikan kesempatan kepada seluruh peserta untuk mengajukan pertanyaan kepada narasumber. Penyampaian pertanyaan dapat dilakukan secara langsung (open mic) maupun melalui chat box. Moderator mengalokasikan waktu sekitar 45 menit. Pertanyaan yang diajukan seputar materi PPS dan kepatuhan pajak sesuai dengan materi yang disampaikan oleh narasumber. Namun demikian, moderator juga membolehkan para peserta bertanya di luar materi sepanjang masih terkait dengan pajak (Gambar 3 dan Gambar 4). 


\section{PENGMASKU}

Volume 1 No. 2, Desember 2021

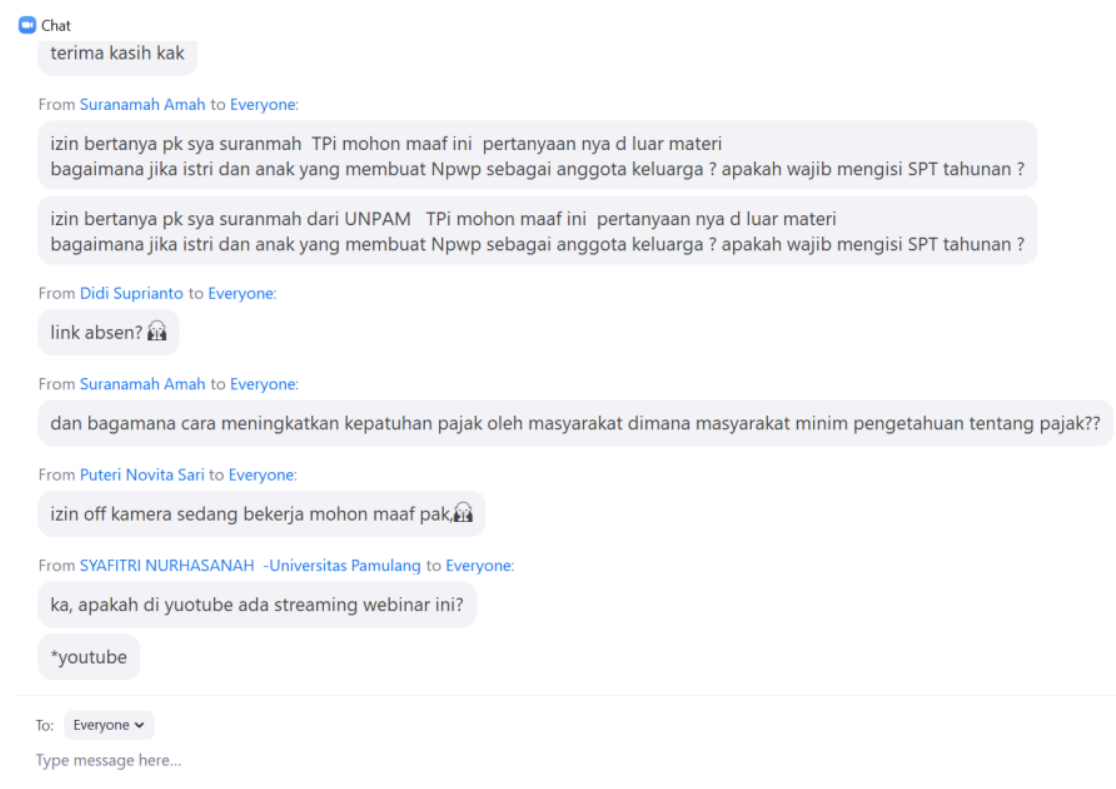

Gambar 3. Sesi Pertanyaan 1

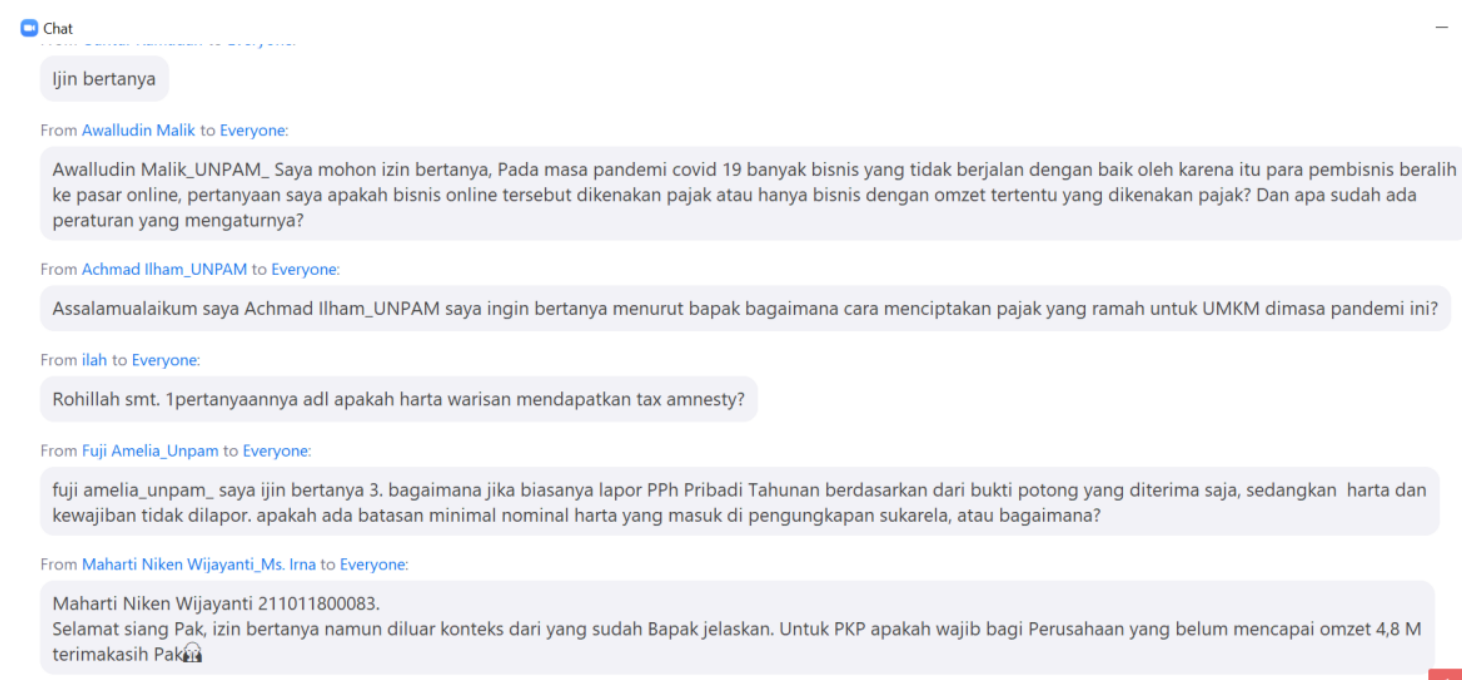

Gambar 4. Sesi Pertanyaan 2

\section{HASIL DAN PEMBAHASAN}

Narasumber pertama menyampaikan beberapa hal utama, yaitu: (a) peranan pajak, (b) perkembangan penerimaan pajak, (c) latar belakang UU HPP, (d) program pengungkapan sukarela (PPS) WP, (e) lesson learned dari program tax amnesty, dan (f) risiko program PPS. Berikut uraian materi dimaksud. Pertama, dijelaskan bahwa penunjang utama APBN sebelum Tahun 1983 di Indonesia adalah sumber daya alam sebesar 67,6\%. Sementara pajak hanya berkontribusi sebesar 22,1\%. Namun, seiring dengan berjalannya reformasi pajak (tax reform), kontribusi penerimaan pajak mulai meningkat pada tahun 1992 yaitu sebesar 47,4\%. Di sisi lain, kontribusi sumber daya alam menurun menjadi sekitar 41,3\%. Pada tahun 2016 dan 2017, kontribusi penerimaan pajak melonjak menjadi sekitar $71 \%$ dari total penerimaan negara (Gambar 5). 


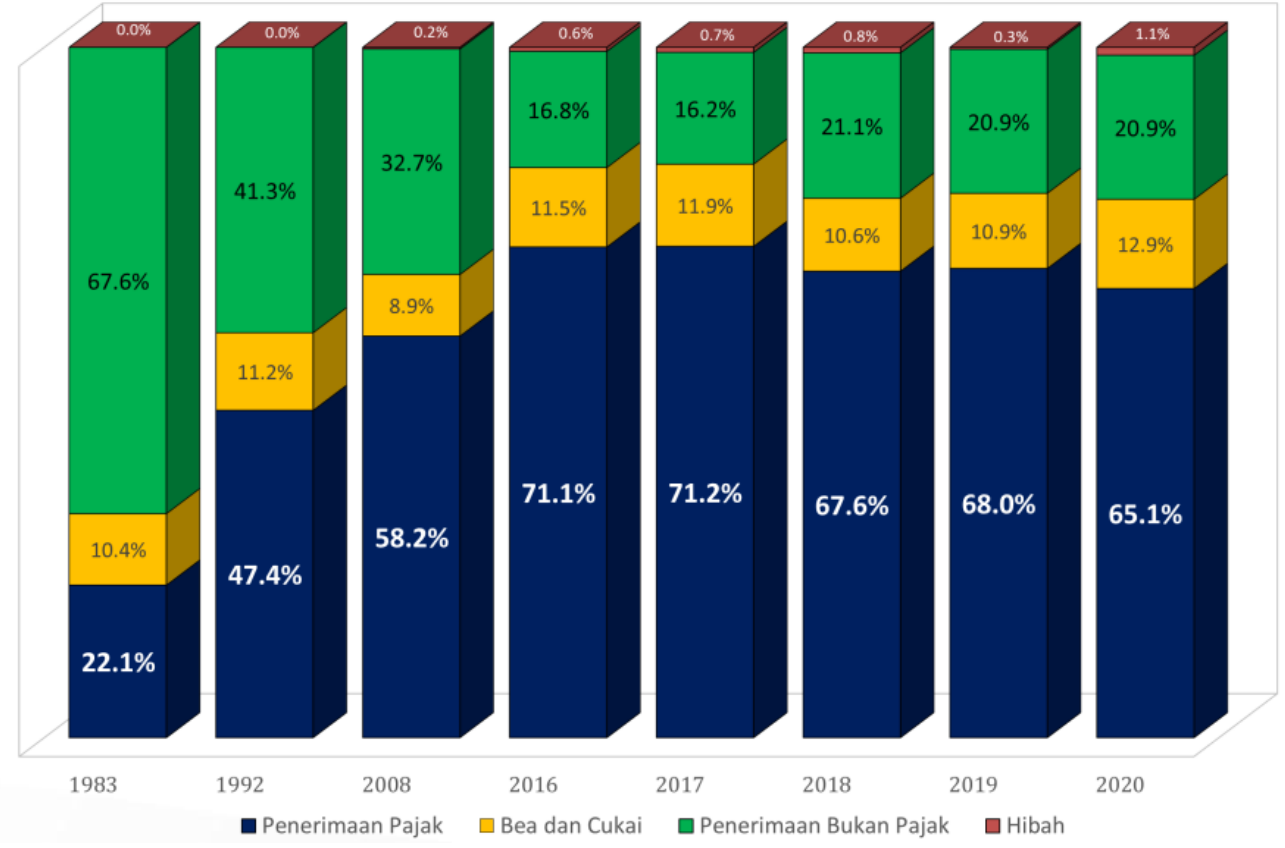

Gambar 5. Penerimaan Pajak

Selanjutnya, narasumber pertama menjelaskan latar belakang terbitnya UU HPP, antara lain disebabkan beberapa hal, seperti: dampak covid-19 terhadap perekonomian, keterbatasan ruang fiskal, fungsi distribusi APBN, tax ratio Indonesia masih rendah, peluang faktor demografi dan peningkatan kepatuhan sukarela wajib pajak. Pada sesi berikutnya dijelaskan pula mengenai PPS termasuk latar belakang, tarif dan ruang lingkup PPS. Berikutnya, narasumber pertama juga menjelaskan mengenai kesuksesan dari program tax amnesty tahun 2016-2017. Kepatuhan penyampaian SPT Tahunan oleh wajib pajak peserta tax amnesty meningkat dibandingkan tahun pajak sebelumnya (gambar 6). Kesuksesan ini diharapkan dapat diikuti oleh PPS.

RASIO KEPATUHAN MENINGKAT PASCA TA 2016

SPT Tahunan meningkat di kisaran 70 persen

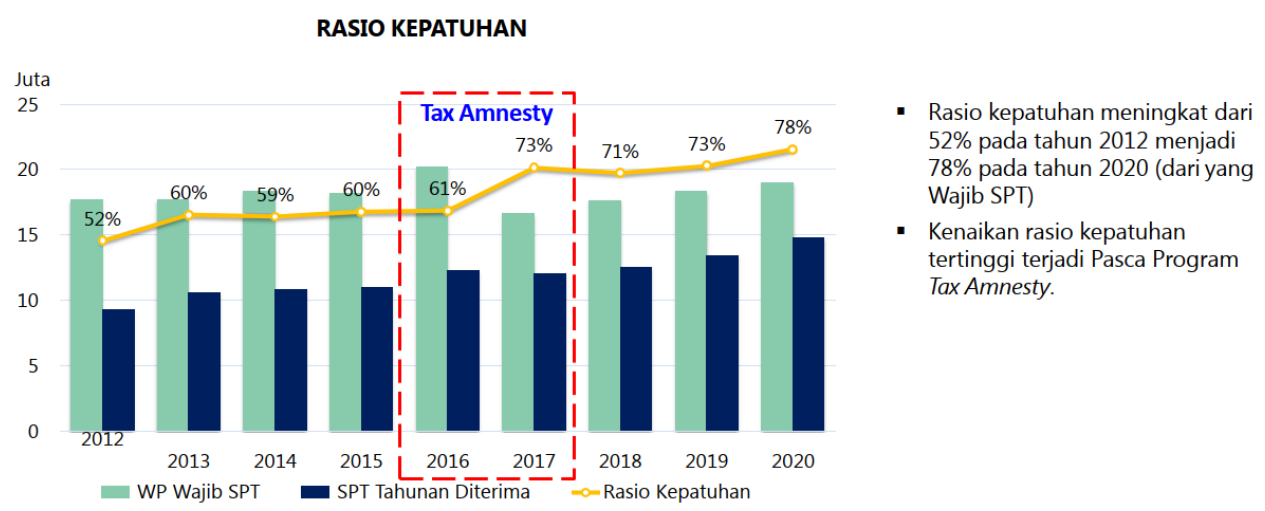

Gambar 6. Rasio Kepatuhan Pajak Pasca Tax Amnesty

Pada bagian akhir, narasumber pertama juga kemudian menjelaskan implikasi dari program pengungkapan sukarela dari perspektif jangka pendek dan jangka panjang. Dalam jangka pendek PPS dapat mendorong penerimaan pajak yang optimal. Namun, di sisi lain memberikan citra bahwa pemerintah tidak konsisten dalam mengeluarkan kebijakan. Dalam jangka panjang PPS dapat mempengaruhi tingkat kepatuhan wajib pajak. Hal ini dapat 
disebabkan adanya harapan dari wajib pajak bahwa program serupa akan dikeluarkan kembali di masa yang akan datang.

Selanjutnya sesi pemaparan dari narasumber kedua yang memiliki irisan dengan materi narasumber pertama. Perbedaan yang signifikan dari materi kedua narasumber tersebut adalah pada model kepatuhan. Kepatuhan pajak dilihat dari berbagai sudut pandang dan model yang berbeda-beda. Model pertama menyatakan bahwa kepatuhan pajak dipengaruhi oleh kompleksitas pajak, moral pajak dan kewajaran pajak (Taing \& Chang, 2021). Model kedua berpendapat bahwa kepatuhan pajak sukarela dipengaruhi oleh audit probability, reputasi perusahaan dan kepemilikan bisnis (Nguyen et al., 2020). Model ketiga yang diajukan oleh Batrancea et al. (2019) berargumen bahwa kepatuhan pajak dipengaruhi oleh kepercayaan kepada otoritas (trust in authorities) dan kekuasaan otoritas (power of authorities). Keempat, Studi yang dikembangkan oleh da Silva et al. (2019) menyimpulkan bahwa kepercayaan terhadap pemerintah memengaruhi kepatuhan sukarela (voluntary compliance), dan pemaksaan kekuasaan memengaruhi kepatuhan yang dipaksakan (forced compliance). Model kelima digagas oleh Lederman (2018) dengan observasi dilakukan di Amerika Serikat menyimpulkan bahwa intensitas audit yang dilakukan oleh otoritas pajak dapat meningkatkan kepatuhan pajak. Selanjutnya model keenam yang diajukan oleh Fuentes-Nieva (2021) menyebutkan bahwa kepercayaan terhadap pemerintah dan kewajaran/keadilan dalam sistem administrasi pajak dapat memengaruhi kepatuhan pajak.

Bank Dunia (World Bank, 2019) memperkenalkan model kepatuhan pajak sebagaimana tertera dalam Gambar 7 berikut.

\section{Theory of Change for Innovation in Tax Compliance}

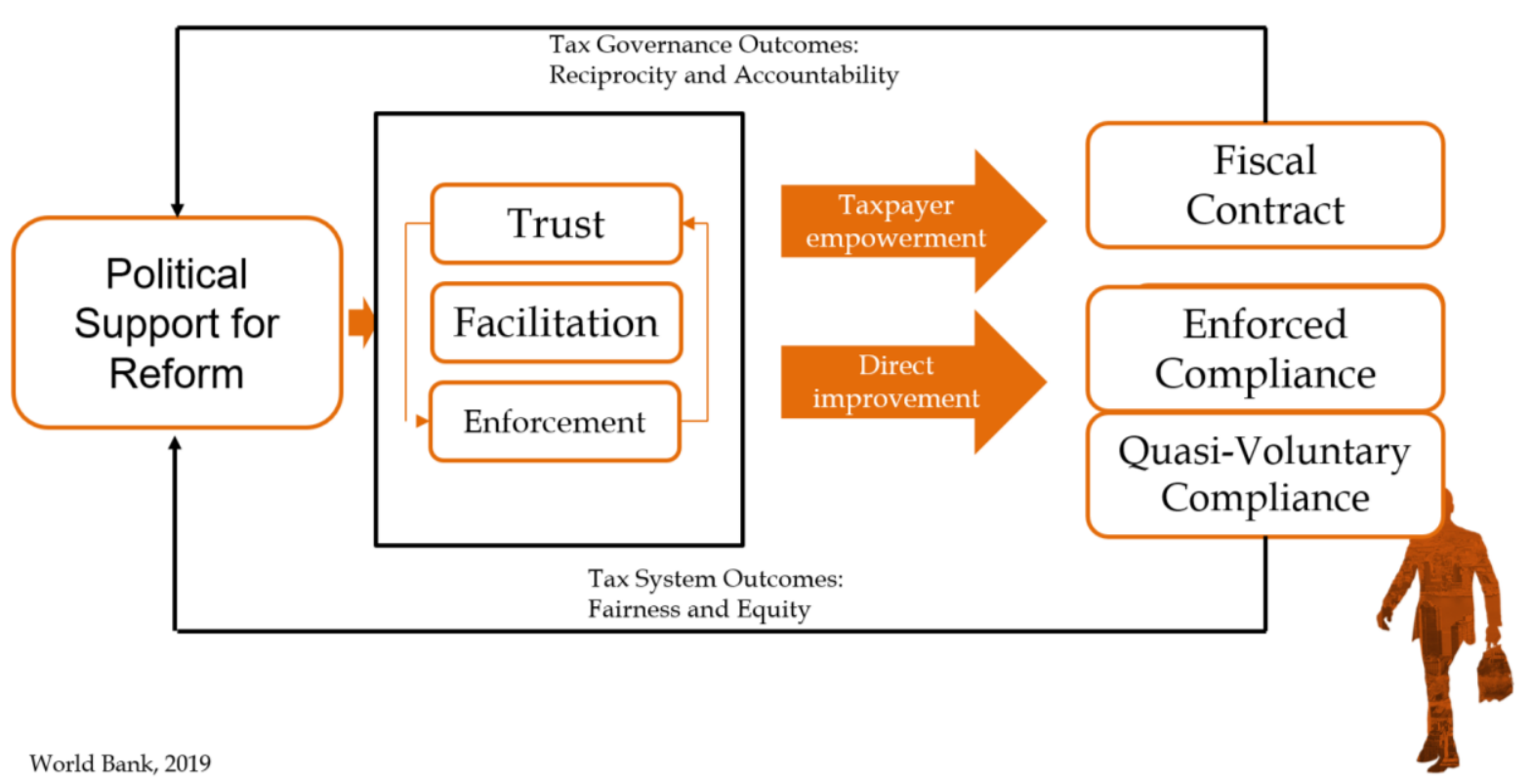

Gambar 7. Model Kepatuhan Pajak versi Bank Dunia, 2019

Gambar 7 menjelaskan siklus dalam kepatuhan pajak. Nampak bahwa dukungan politis dari masyarakat sangat diperlukan dalam sistem administrasi pajak. Dukungan ini dapat menciptakan kepercayaan masyarakat sehingga wajib pajak menjadi sadar dan patuh pajak. Kemudian, akan tercipta kontrak fiskal antara pemerintah dan wajib pajak sehingga pada gilirannya menciptakan dukungan kepada pemerintah.

Sesi berikutnya dilanjutkan dengan sesi tanya jawab. Terdapat cukup banyak pertanyaan namun karena terbatasnya waktu, hanya beberapa pertanyaan saja yang dapat dijawab oleh narasumber. Pertanyaan pertama adalah apakah anak dan istri yang memiliki NPWP 


\section{PENGMASKU}

Volume 1 No. 2, Desember 2021

mempunyai kewajiban untuk melaporkan SPT (Tahunan)? Atas pertanyaan ini narasumber menjawab bahwa pada prinsipnya kewajiban pajak itu hanya satu untuk setiap keluarga dalam hal ini diwakili oleh ayah sebagai kepala keluarga. Namun demikian, bagi anak yang berusia di atas 18 tahun diperbolehkan memiliki NPWP sendiri apabila telah memiliki penghasilan di atas penghasilan tidak kena pajak (PTKP) sesuai ketentuan yang berlaku. Selain itu dijelaskan pula bahwa bagi istri yang berpenghasilan dan ingin melaporkan sendiri SPT Tahunan PPh sebenarnya dapat juga menggunakan NPWP suami atau menggunakan NPWP sendiri sepanjang hal tersebut dikehendaki. Ketentuan ini diatur dalam UU PPh.

Pertanyaan kedua yang diajukan adalah bagaimana ketentuan pemajakan bagi bisnis yang dijalankan secara online? Apakah dikenakan pajak berdasarkan omset tertentu dan apakah ada ketentuan yang mengatur secara spesifik. Atas pertanyaan ini respon narasumber adalah sebagai berikut. Pada prinsipnya, menjalankan bisnis secara online maupun konvensional hanya merupakan media dalam memperoleh penghasilan. Bahasan terpentingnya ada pada nilai transaksi yang dilakukan. Dalam UU HPP diatur bahwa bagi wajib pajak orang pribadi (WP OP) yang dikenakan PPh bersifat final tidak dikenai pajak untuk bagian dari omset sampai dengan Rp 500 juta.

Pertanyaan ketiga adalah bagaimana menciptakan pajak yang ramah untuk UMKM di masa pandemi. Narasumber menjelaskan bahwa di masa pandemi pemerintah melakukan berbagai kebijakan untuk pemulihan ekonomi nasional, termasuk di antaranya adalah memberikan insentif dan fasilitas di bidang perpajakan. Untuk UMKM sendiri diberikan insentif sebagaimana dijelaskan dalam jawaban atas pertanyaan kedua tersebut di atas.

Pertanyaan keempat yang disampaikan oleh peserta adalah bagaimana jika wajib pajak orang pribadi melaporkan penghasilan dalam SPT Tahunan hanya sebatas pada penghasilan yang tercantum dalam bukti potong saja (tanpa memasukkan jumlah harta dan kewajiban). Atas pertanyaan ini dijelaskan bahwa secara teknis pelaporan SPT Tahuna PPh Orang Pribadi telah diatur apa saja yang harus dilaporkan sesuai dengan klasifikasi wajib pajak dimaksud. Terdapat tiga klasifikasi SPT Tahunan PPh yang dapat digunakan oleh wajib pajak orang pribadi yaitu, SPT 1770, SPT 1770S dan SPT 1770SS. Wajib pajak dapat melihat kembali jenis SPT apa yang sesuai dengan kondisi penghasilan yang dimilikinya.

\section{PENUTUP}

\section{Simpulan}

Berdasarkan umpan balik yang diberikan oleh para peserta, dapat diketahui bahwa webinar seperti ini sangat bermanfaat dalam menambah pengetahuan dan praktik perpajakan khususnya terkait dengan program pengungkapan sukarela yang mulai berlaku tahun 2020 . Selanjutnya, PPS ini hendaknya didukung oleh seluruh wajib pajak sehingga tujuan yang diinginkan dapat tercapai yaitu penerimaan pajak yang optimal melalui peningkatan kepatuhan.

\section{Saran}

Sesuai dengan jumlah pertanyaan yang diajukan baik langsung maupun melalui chat box nampak bahwa antusiasme peserta sangat besar sekali. Untuk itu, diperlukan waktu tambahan bagi sesi tanya jawab. Alternatif lainnya memberikan media khusus di luar webinar untuk dapat menjawab setiap pertanyaan yang diajukan.

\section{DAFTAR PUSTAKA}

Batrancea, L., Nichita, A., Olsen, J., Kogler, C., Kirchler, E., Hoelzl, E., Weiss, A., Torgler, B., Fooken, J., Fuller, J., Schaffner, M., Banuri, S., Hassanein, M., Alarcón-García, G., Aldemir, C., Apostol, O., Bank Weinberg, D., Batrancea, I., Belianin, A., ... Zukauskas, 
S. (2019). Trust and power as determinants of tax compliance across 44 nations. Journal of Economic Psychology, 74, 1-68. https://doi.org/10.1016/j.joep.2019.102191.

da Silva, F. P., Guerreiro, R., \& Flores, E. (2019). Voluntary versus enforced tax compliance: the slippery slope framework in the Brazilian context. International Review of Economics. 66(2), 147-180. https://doi.org/10.1007/s12232-019-00321-0.

Fuentes-Nieva, R. (2021). The Way We Voluntarily Pay Taxes. https://cic.nyu.edu/sites/default/files/the_way_we_voluntarily_pay_taxes_may_2021_0.p df.

Irawan, F. (2021). Pelatihan Melalui Web Seminar Dampak UU HPP terhadap Pelaku UMKM di Era Pandemi, Pengmasku, 1(1), 22-28.

Lederman, L. (2018). Does Enforcement Reduce Voluntary Tax Compliance? BYU Law Review, 2018(3),623-694. https://digitalcommons.law.byu.edu/lawreview/vol2018/iss3/6

Nguyen, T. T. D., Pham, T. M. L., Le, T. T., Truong, T. H. L., \& Tran, M. D. (2020). Determinants influencing tax compliance: The case of Vietnam. Journal of Asian Finance, Economics and Business, 7(2), 65-73. https://doi.org/10.13106/jafeb.2020.vol7.no2.65.

Taing, H. B., \& Chang, Y. (2021). Determinants of Tax Compliance Intention: Focus on the Theory of Planned Behavior. International Journal of Public Administration, 44(1), 6273. https://doi.org/10.1080/01900692.2020.1728313.

World Bank (2019). Innovations in Tax Compliance Transparency Tax and Trust. https://www.worldbank.org/en/topic/macroeconomics/brief/innovations-in-taxcompliance 